\title{
Innovation and the Success of Women's Small Scale Enterprises in Ghana
}

\author{
Smile Dzisi ${ }^{1}$, Christopher Selvarajah ${ }^{2}$ \\ ${ }^{1}$ Department of Purchasing and Supply Koforidua Polytechnic, P. O. Box 981, Koforidua, Ghana \\ Email:afuasmile@yahoo.com \\ ${ }^{2}$ Faculty of Business E Enterprise Mail H23,Swinburne University, PO Box 218Hawthorn VIC 3122, Australia, \\ Email:cselvarajah@swin.edu.au
}

\begin{abstract}
Innovation is fast becoming a crucial factor in enterprise performance, growth and survival. In recent years, a growing number of studies have demonstrated how innovation leads to success in larger enterprises. Literature addressing innovation in small enterprises in developing countries is limited; most studies in this field are from developed countries. This study therefore aimed at filling the gap by firstly, exploring the innovations introduced in the Ghanaian women-owned small enterprises, and secondly finding out the relationship between these innovations and the women's business success. The innovative practices explored were the introduction of new products and processes, identification of new sources of raw materials and new markets. Quantitative and qualitative approaches are combined in data collection and analysis. Data has been obtained from a survey of 421 Ghanaian women entrepreneurs and interviews conducted with 50 of those women. The results in the study indicated that the small enterprises engaged in various types of innovative practices such as the adoption of fuel efficient processing methods, diversification of product line, improved packaging and opening of new market outlets. These innovative practices have contributed to the success of the enterprises. Their success factors include self-fulfillment, wealth creation and positive impact on the Ghanaian economy. These findings have policy implications for improved technology and funds allocation to enhance women's role in economic development.
\end{abstract}

Keywords: Innovation; Business growth; Women-owned small enterprises; Schumpeter's entrepreneurship perspective.

\section{Introduction}

Globally, Small and Medium Enterprises (SMEs) are recognized for their significant contribution to economic growth and development, employment and the social progress of economies (OECD, 2004; UNCTD, 2005). SMEs have also been widely acknowledged in literature as the vehicles in which entrepreneurship thrives (Brush et al., 2006; Wennekers and Thurik, 1999). Promoting a country's SME sector is instrumental in maintaining high employment and income generation and is therefore critical for achieving sustainable economic growth. Several studies and research findings have pointed to the fact that women entrepreneurs, compared to their male counterparts, are more involved in SMEs and are observed to be very successful in the sector (Brush et al., 2006; Butler, 2003; Coughlin, 2002; OECD, 2004).

Innovation is considered as the lifeblood of every enterprise and entrepreneurship scholars recognize the critical role of innovation in the success of businesses. The role of innovation and its importance as a driver of competitiveness, profitability and productivity in SMEs have been confirmed in literature (Fazlzadeh and Moshiri, 2010; O'Regan et al., 2006). According to Lemon and Sahota (2004), innovation consists of successfully implementing creative ideas within an enterprise resulting in productivity and creation of wealth. Interestingly, women, as a result of their increasing entrepreneurial activities (Jalbert, 2000; OECD, 2004), are perceived as a great source of innovation and employment in the twenty-first century. Women entrepreneurs create jobs for themselves and others, by being different. They also provide society with different solutions to management, organization and business problems as well as to the exploitation of entrepreneurial opportunities.

Research in female entrepreneurship, mostly in developed countries, highlighted the innovative practices of the women-owned small scale enterprises (Brush et al., 2006; Coughlin, 2002; OECD, 2004). These studies have found positive significant relation between the women's innovative practices in their enterprises and their business success and growth. These studies showed that, through their 
innovative activities, the women's small enterprises in all Organization for Economic Co-operation and Development (OECD) countries and other developed countries have contributed significantly to the socioeconomic development of their countries (OECD, 2004). Several researchers have testified that womenowned small enterprises in those countries represented an economic strength that is able to generate both substantial sales and employment for the women themselves and for others (Brush et al., 2006; Coughlin, 2002).

Despite such information on innovative small business formation and the economic contribution of women in developed countries, little is known of women entrepreneurs in developing countries, particularly Ghana. The majority $(85 \%)$ of the Ghanaian female labour is in self-employment (Ghana Statistical Services, 2002). Researchers (Britwum et al., 2006) found that in addition to the Ghanaian women's traditional responsibilities of performing household chores and looking after the family, they engage in various productive and innovative ventures that contribute to economic growth. Dzisi and Seddoh (2009) have also observed that researches conducted in the field of innovations and their relation with success in developing economies concentrated mainly on large firms and that relatively little work has been done to identify innovative practices in women-owned small enterprises and how these innovations lead to their success. Therefore, studies into innovation practices employed in the women-owned small enterprises in Ghana will accelerate and achieve greater productivity and advancement of the Ghanaian economy and success in today's global competition.

Many researchers (for example, Dzisi, 2009; Hisrich and Ozturk, 1999; Montalvo, 2006; Oke et al., 2007) have argued strongly that using the findings of innovation studies in advanced countries to explain the innovative behaviour in less developed countries is likely to be inappropriate. This line of thinking is supported by differences in national conditions that affect firm conduct and innovative performance. Ghana's predominantly strong family orientation, culture, and low level of education for women, coupled with its low income economic status differentiate it from many developed countries.

Hence, a study of the innovative practices in the Ghanaian women-owned small scale enterprises and their link with success would add to knowledge about women entrepreneurial activities in the SME sector generally and its findings may be useful specifically for developing countries. Exploring their success would lead to the recognition of the economic abilities and social contributions these Ghanaian women entrepreneurs are making to their country. The study would be a strong case for improving support for SMEs in general, and, in particular, for women-operated small enterprises.

The present study therefore aimed at exploring the innovative practices of Ghanaian women-owned small enterprises and the relationship between these innovations and their success. Pertinent questions the research wanted to find answers to were: (i) which new products have been introduced? (ii) which new processes or methods have been adopted? (iii) which new sources of raw materials have been identified? (iv) has there been conquest of new markets, and adoption of new marketing strategies by these small scale enterprises? (v) have these innovations resulted in the business success of the women-owned enterprises?

Joseph Schumpeter's economic model of entrepreneurship has been adopted to guide the study in finding answers to these questions

\section{Schumpeter's economic model of entrepreneurship}

Schumpeter was the economist who has most prominently drawn attention to the innovating entrepreneur. Schumpeter (1961) argued that innovation meant doing more with the same amount of resources available to anyone. Schumpeter also regarded the entrepreneur as the one who contributes significantly more than others to the economy by virtue of innovation. This always goes together with the loss of old products and processes. Schumpeter called that creative destruction (Schumpeter 1934). Schumpeter stated that the term innovation fits into either of the five categories: the creation of a new product, a new method of production, the opening of a new market, the capture of a new source of supply or a new organization of industry.

Schumpeter (1979) further argued that every innovation successfully introduced by business firms, large or small, creates new demand for goods and services and therefore creates new wealth and success for the entrepreneur. Choi (1995) and Kirzner (1999), in supporting this perspective, added that although innovations can vary in their degree of radicalness, innovativeness represents a basic willingness to depart from existing technologies or practices and venture beyond the current state of the art. Schumpeter's perspective is strongly affirmed in business literature in that the choice of industry sector and the type of business activity undertaken has a direct effect on 
potential growth and success. Bhide (2000) also added that innovative business ventures that are not easily imitated are more likely to attract high patronage, and create wealth.

In support of Schumpeter's innovation perspective, Linder, et al., 2003) described innovation as "implementing new ideas that create value". This generic description refers to the various forms that innovation can take such as product development, the deployment of new process technologies or innovative management practices (Glynn, 1996; Zott, 2003). From a practitioner's perspective, this means the adoption of new products and/or processes to increase competitiveness and overall profitability, based on customer needs and requirements (Mone et al.,1998 ; Zahra et al.,1999). Effective innovation therefore means that SMEs need to maximize the creative resources that they possess (O'Regan et al., 2006).

In this study we have built on the earlier works of Schumpeter and other recent works of researchers (such as Britwum et al., 2006; Fazlzadeh and Moshiri, 2010; Kirzner 1999; Montalvo 2006; OECD 2004) in developing an entrepreneurship framework that seeks to identify the innovative practices in women-owned small enterprises in Ghana. This is to find out whether they exhibit the innovative characteristics (the creation of a new product, a new method of production, the opening of a new market, the capture of a new source of supply, or a new organization of industry) advocated by entrepreneurship theorists.

\section{Interpretation of success}

Interest in successful small businesses continues to grow. The interest is, however, influenced by the different ways in which small businesses are categorized. Scholars have provided many reasons for business success and their research contributions have created discrepancies within literature by reporting on different variables that contribute to success. There is a range of criteria associated with success in terms of individual owner characteristics, business size, profitability, organizational values and performance measures (Bird and Sapp, 2004; Simpson, et al.,2004). Traditional economics and entrepreneurship theories interpret success of a business based on its financial performance and profitability (Djik 1996). However, more recently, there is a growing argument that the definitions of success need to include non-financial yardsticks such as the level of self fulfillment and personal achievement (Brush et al.,2006; Still and Timms 2000). This argument is strongly used in the women's entrepreneurship literature (Bennet and Dann, 2000; Brush et al., 2006; Buttner and Moore, 1997; Still and Timms, 2000).

Furthermore, a critical review of the literature on the definition of business success has confirmed Simpson et al., (2004) observation that few researchers have consulted owners/managers about their views on success. Therefore in this present study, both financial and non-financial yardsticks have been used to explore the concept of business success in terms of what it means to the women entrepreneurs in Ghana. That was to help to investigate which factors explain their success.

\section{Hypothesis of the study}

Based on the literature review and empirical research studies, the following hypothesis will be tested for innovative practices and success of the women-owned small enterprises in Ghana:

H1: There is a significant relationship between new product development and success of the women-owned small enterprises in Ghana

$\mathrm{H} 2$ : There is a significant relationship between new methods of production and success of the women-owned small enterprises in Ghana

H3: There is a significant relationship between new sources of raw materials and success of the women-owned small enterprises in Ghana

$\mathrm{H} 4$ : There is a significant relationship between new market outlets, and success of the womenowned small enterprises in Ghana

\section{Methodology}

The target population of the study was womenowned small enterprises in the Eastern Region of Ghana. According to the Ghana Statistical Service Report (2002), Eastern Region has a high population $(68 \%)$ of the women owned-small businesses in Ghana. The database of women-owned enterprises in the region was obtained from the Eastern Regional Office of the National Board of Small Scale Industries (NBSSI) - a governmental implementing agency responsible for micro and small businesses in Ghana. The major criterion applied to identify the small enterprises was Steel and Webster's (1990) definition of small businesses in Ghana. Steel and Webster's definition of small businesses disaggregated them into three categories: micro-employing up to five people; very small-employing six to nine people; small - 
employing 10 to 29 people. Hence, all the womenowned enterprises employing 0 to 29 people in the Eastern Region of Ghana numbering 680 formed the population of the study.

The study employed a mixed methodology research design where both qualitative and quantitative methods were used. Stratified random sampling method was employed to select 510 enterprises out of 680 for data collection. These sampling techniques ensured representation from the entire population in the study and avoided bias. To collect quantitative data, survey questionnaire were administered to the 510 women-owned enterprises covering all the industries where the women's businesses were found. 421 usable responses were received making a proportion of $(421 / 510 \times 100)$ representing approximately $83 \%$ response rate. In addition, fifty (50) enterprises from all the industries were purposively selected from the survey participants for face-to-face interviews, to gain deeper insight into the phenomenon under study. The breakdown of the population, sample size, survey responses and interviews according to the seven (7) categories of the small enterprises' industries classifications were presented in Table 1. The qualitative data was analyzed manually with content analytic method. That was followed by a quantitative analysis of the survey data by the use of statistical techniques such as descriptive analysis and Chi-square test.

Table 1

Breakdown of the study's population, sample size and responses

\begin{tabular}{lcccc}
\hline Category (Industry) & Population & Sample size & Survey Responses (\%) & Interviews \& Observations \\
\hline Trading & 180 & 115 & $108(93 \%)$ & 10 \\
Manufacturing/Production & 85 & 65 & $50(77 \%)$ & 6 \\
Construction & 36 & 30 & $17(57 \%)$ & 4 \\
Services & 140 & 100 & $87(87 \%)$ & 10 \\
Agriculture & 30 & 25 & $67(84 \%)$ & 4 \\
Agro-Processing & 87 & 70 & $21(70 \%)$ & 6 \\
Education & 40 & 30 & $50(67 \%)$ & 4 \\
Textile \& Fabric & 82 & 75 & $421(83 \%)$ & 6 \\
Total & 680 & 510 & & 50 \\
\hline
\end{tabular}

\section{Discussion of results}

\section{1 Demographics of the sample-personal and business}

It was found that the women who own the small enterprises in the Eastern Region of Ghana, mainly constituted the economically active age groups, that is, between 21 and 51 years old (67\%). The respondents ranged in age from 21 to 60 years. The results further show that a significant percentage (70\%) of these women are married and have an average of four (4) children. The findings on their educational background indicate that over half $(76 \%)$ of the respondents attained only a basic level of education. Few of them (24\%) had a secondary/high school/college education.

Concerning their businesses, the results further showed that on the average, across the respondents, the businesses have existed for 10 years, although the range was from 1 to 25 years. On the number of employees, the findings showed that most $(76 \%)$ of the respondents did not employ anyone at the commencement of their businesses. Currently, the number of people employed ranged from 0 to 9 . The study found that the women-owned small enterprises comprised of all the seven (7) broad classifications of the National Board for Small Scale Industries (NBSSI) in Ghana (refer to table 2). This means that the range of small businesses operated by the women entrepreneurs in Ghana is diverse and cuts across trading, services, manufacturing/production, construction, agriculture, agro processing, education, textile and fabric industries. The results indicated that the majority of the women entrepreneurs $(79 \%)$ have created their small enterprises from scratch, while some $(21 \%)$ of them have taken over existing businesses from relatives and modified them.

The majority of the women-owned small enterprises in Ghana were in the trading (26\%) and services $(21 \%)$ sectors. The rest were spread across agro-processing $(16 \%)$, manufacturing $(12 \%)$, textiles and fabrics $(12 \%)$, agriculture $(5 \%)$, education $(5 \%)$, and construction sector (4\%). The results seemed to 
coincide with other researchers' findings, such as Singh et al., (2001), Spring 2005 and Tinker 1990, that the women-owned small businesses in developing countries are concentrated in the trade and services sectors. However, the results from the present study also highlighted that the small business ventures of the women entrepreneurs in Ghana were not limited to these sectors. Of particular interest is the fact that the women entrepreneurs in Ghana are making inroads into non-traditional industries for women. A notable percentage of the business ventures were located in the manufacturing (12\%) and construction (4\%) sectors.

\section{Table 2}

Ghanaian women's small enterprises: industry sectors and types of business ventures

\begin{tabular}{|c|c|c|c|}
\hline $\begin{array}{l}\text { Industry } \\
\text { Sectors }\end{array}$ & Types of Business Ventures & $\begin{array}{l}\text { Number of } \\
\text { Women } \\
\text { Entrepreneurs }\end{array}$ & Total (\%) \\
\hline Trading (V & $\begin{array}{l}\text { Wholesale/Retail) } \\
\text { Building supplies } \\
\text { Children clothing } \\
\text { Clothing (unisex) } \\
\text { Jewelry } \\
\text { Imported food (bags of rice, } \\
\text { sugar and vegetables oil) } \\
\text { Soft drinks and Alcoholic } \\
\text { beverages } \\
\text { Foodstuffs } \\
\text { Kitchenware } \\
\text { Fashion leather bags } \\
\text { Frozen meat, poultry and fish } \\
\text { Fabrics } \\
\text { Hair products and cosmetics }\end{array}$ & $\begin{array}{r}14 \\
12 \\
7 \\
7 \\
9 \\
9 \\
8 \\
11\end{array}$ & $108(26 \%)$ \\
\hline Manufactu & $\begin{array}{l}\text { uring/Production } \\
\text { Hair products (shampoo, } \\
\text { conditioners, hair pomade) } \\
\text { Detergents, toilet soap } \\
\text { Cosmetics (powder, cream, pomade) } \\
\text { Jewelry (rings, bracelets, necklaces, } \\
\text { earrings) } \\
\text { Beads } \\
\text { Pottery }\end{array}$ & $\begin{array}{r}6 \\
4 \\
6 \\
\\
6 \\
15 \\
13\end{array}$ & $50(12 \%)$ \\
\hline Constructi & $\begin{array}{l}\text { Residential } \\
\text { Schools and Office Complexes } \\
\text { Sandcrete Production }\end{array}$ & $\begin{array}{l}5 \\
5 \\
7\end{array}$ & $17 \quad(4 \%)$ \\
\hline Services & $\begin{array}{l}\text { Restaurants } \\
\text { Small Scale Catering Services, bakery } \\
\text { Hairdressing Saloon/Decoration, } \\
\text { Bridal dressing/Florists } \\
\text { Dressmakers/Fashion designers }\end{array}$ & $\begin{array}{l}14 \\
24\end{array}$ & $87(21 \%)$ \\
\hline Agricultur & $\begin{array}{l}\text { Vegetable Farm } \\
\text { Poultry and Livestock }\end{array}$ & $\begin{array}{r}3 \\
18\end{array}$ & $21 \quad(5 \%)$ \\
\hline
\end{tabular}

$\begin{array}{crrr}\text { Agro-Processing } & & 67(16 \%) \\ \text { Fish Processing } & 6 & & \\ \text { Gari Processing } & 14 & & \\ \text { Palm oil Processing } & 19 & & \\ \text { Shea Butter Processing } & 5 & & \\ \text { Palm Kernel oil Processing } & 11 & & \\ \text { Fruit juice Processing } & 3 & & \\ \text { Mineral Water Processing } & 9 & 21 \quad(5 \%) \\ \text { Education } & 17 & & \\ \text { Pre School (Childcare) } & 2 & & \\ \text { PreSchool to JHS and SHS } & 2 & & \\ \text { Vocational Schools } & & & \\ \text { Textile and Fabric } & 26 & & \\ \text { Batik making } & & & \\ \text { Local Tie and Dye fabric } & 24 & \\ \text { making } & & \end{array}$

\subsection{Innovation: Introduction of new products}

The trading sector was dominated by retailers who traded in a variety of products including clothing, cosmetics, foodstuffs, jewellery, plastic ware and kitchen utensils. It is clear from the study that women who operated small scale trading enterprises initially traded in only one product like baby clothing. But with time, when they realized that the sale of one item was not yielding much profit, they added on other items whose demands were high in the market; for example ladies shoes and bags and adult clothing. They diversified their businesses by adding new product lines or changing the items they traded in. With that innovation their businesses did not make losses if one product was not well patronized. They made profit from the other items to keep the business going.

The respondents' dominant business activities in the manufacturing sector were a variety of innovative designed handicraft making. Some (9\%) of the respondents were engaged in variety of jewellery making (gold and silver rings, chains, bracelets, earrings), assorted bead and pottery making. A few $(3 \%)$ of the respondents in the manufacturing sector were involved in soap, detergent, cosmetics and shampoo production. It was also found that most of the small scale manufacturing enterprises started with manufacturing of hair pomade, and have added new product lines like manufacturing of detergents, hair shampoo and conditioners. That has resulted in more profit.

Furthermore, it was revealed during the survey and the interviews that about $90 \%$ of the construction companies started with sandcrete production and have gradually progressed into the construction of 
residential facilities. The unique features of their businesses were that the women targeted low and middle income level workers and were designing and building affordable housing units for them. That innovative housing product has expanded the women's customers' base.

In the service sector it was found that the small business ventures of the women entrepreneurs were predominantly in catering services $(8 \%)$ including restaurants, snack shops, rest stops and bakeries. The results indicated that most of the women in the catering service sector started as fast food operators or hawkers. Currently all of them served variety of meals both local and continental. They also provide catering services at funerals, weddings and other festive occasions. Fashion designing and dressmaking $(5 \%)$; hairdressing $(5 \%)$, and interior decoration (3\%) are also some areas where the women-owned enterprises operating in the service sector. The study identified that hairdressers in the service sector no longer concentrated on shampooing and setting of hair only. They have diversified into braiding of hair and fixing different innovative hairstyle to satisfy their customers. Additionally, the women sold hair products, soft drinks, pastries, women wear and mobile phone credits in their hair-dressing salon to earn extra income.

An industry sector that some $(12 \%)$ of the respondents were found in was textiles and fabrics; for example, the weaving of kente (a beautiful Ghanaian traditional cloth), batik, and tie and dye making. The women involved in these ventures were innovative and have the ingenuity and skills to blend different colours to produce beautiful fabric. It was also revealed that the textile and fashion enterprises consistently produced innovative designs that attracted many customers to them.

The results also showed that several business ventures involving different types of food and cash crop processing dominated the agro-processing industry. Good percentages (16\%) of the women's business ventures in the agro-processing industry were in food, oil, fruit, and cash crop processing. Agro-processing is a unique industry where food and other end-products are produced by adding value to raw produce from food and cash crops as well as fish from both marine and inland sources. The results indicated that the initial product from palm fruit processing was edible oil popularly known as zomi. Initially the kernels from the palm fruits were thrown away but there has been a new discovery whereby the kernels were cracked, roasted, milled and finally processed to obtain edible oil known as adwengo.
Thus, processors were able to extract two kinds of edible oil (zomi and adwengo) from the same amount of palm fruit. The women involved in cassava processing revealed that their initial product was cassava dough and gari which are staple food in Ghana. Currently, through innovation, they are processing pastry flour. Also, through their innovativeness, the extracted liquid from the grated cassava which was originally poured away is now being processed into starch for laundry purposes. Thus, the women added more product lines to the existing ones. The findings from the agro-processing sector revealed that a significant percentage $(64 \%)$ of the women entrepreneurs themselves discovered the multiple uses of these products (palm fruit and cassava) while some of them (36\%) 'piggy-backed' on the discoveries or engaged in known changes taking place in the sector.

Another sector the women operated in was education. The women entrepreneurs have identified niche markets in the area of pre-schools (childcare). Children start school at age four in Ghana's public sector formal educational system, and no provision is made for children from age 0 to 4 years. Women, especially working mothers and mothers who are students, find it extremely difficult to combine mother care with work or schooling. Women entrepreneurs have particularly identified this problem and solved it by setting up pre-schools to cater for toddlers and infants.

\subsection{New methods of production/processing/ delivery}

In the trading sector, the results indicated that most of the traders now delivered their goods (be it foodstuff, clothing, cosmetics or drinks) to their customers directly at home instead of the customers coming over to the market to purchase the products. Also, the women revealed that they offered various innovative forms of payment to their customers such as monthly or quarterly payment for a product already consumed. In some cases, payments were done in installments. Those processes, according to the women provide them with more customers and also helped them to maintain their customers. According to the women, these credit facilities were mostly offered to their customers who were gainfully employed and their employers acted as a guarantor. With the manufacturing, service and construction sectors new equipment and tools were used for processing their products. The women who operated the restaurants said when they started their businesses 
they only provided services to customers who came to their shop. Currently, they provide a home delivery service which is really profitable.

The data gathered from the agro-processing enterprises showed that the initial process of producing palm oil consisted mainly of boiling and pounding of the palm nuts and then boiling it again to extract the oil through skimming. The process of producing oil was mainly manual demanding considerable amount of physical exertion and time. Most of the respondents have explained that boiling and pounding of the palm fruits as well as cracking of palm kernels have been mechanized.

Findings from the study have also shown that the approach to gari processing has changed over time with the introduction of an improved swish stove (hearth burner system) for roasting. That has greatly enhanced the production process and capacity, and also reduced the health hazards associated with it. Prior to that innovation, the respondents who produce gari explained that they used the traditional swish stove which has been noted for generating a lot of smoke and excessive heat.

The study found that an improved technology in fish processing called 'Chorkor Smoker' or kiln has been adopted by most of the fish processors. Before the adoption of the kiln, fishmongers smoked fish with the traditional smoker made of clay with big openings at the base and spaces at the top edges.

This traditional smoker could only accommodate one layer of fish during smoking. The design of the kiln endowed it with more improved features than the traditional smoker. For example, it could contain up to five layers of fish which allowed easy turning during the smoking process. The kiln is also associated with less smoke and heat, thus improving the quality of fish and reducing the health risk associated with excessive smoke.

\subsection{New sources of raw materials}

The results in the trading sector indicated that the women have changed from buying all their raw materials from middlemen to buying from wholesalers. The traders explained that formerly, they purchased all their goods from retailers and in few instances, wholesaler, but currently the women deal directly or mostly with the factories and buy in large quantities and also at reduced cost. For instance, those who sell foodstuff and those who operate restaurants buy directly from farmers. It was revealed in the agro-processing industry that acquisition of raw materials for the palm oil and palm kernel oil were previously from markets.

Currently, according to the respondents, all the processors have formed a co-operative to cultivate palm plantation in order to have constant source of raw material. The cassava processors also belong to associations made up of cassava farmers and processors. Before coming up with this new source of raw material, the processors were depending totally on the cassava sold in the markets, which was mostly seasonal and unreliable. That adversely affected their production. The fish mongers, in addition to getting fresh fish from the sea and rivers, have linked up with those who have fish farms and ponds. This ensures that they always get constant and adequate supply of fish for processing.

\subsection{New markets and marketing strategies}

All the women operating the small business enterprise admitted that their initial market was their local communities. Currently, a high percentage $(63 \%)$ of the women entrepreneurs' products are found in the regional markets, some percentage (28\%) are in the national markets, and only $(9 \%)$ are in the international markets. Packaging and labeling of the products have also been improved considerably. For instance, the mode of packaging gari has changed. Previously, gari was measured and served into containers brought along by buyers. Today, however, the product is packaged in sachets made from transparent polythene sheets.

Buyers of palm and kernel oil no longer have to carry along their gallons and bottles as sellers now package their oil in bottles and gallons. In the fast foods joints, food is no longer served in polythene bags. Nicely labeled food containers are now used in packaging food and snacks for customers. The hair products and detergents that are produced by the small enterprises are also now well packaged and labeled. This makes the products more attractive and able to compete with similar products in the market.

\subsection{The interpretation of success}

In the results, Ghanaian women entrepreneurs interpret success in a very broad context. For them the meaning of success relates to a cluster of attributes including self-fulfillment and accomplishment (95\%), financial success and family security (92\%) and contributions to their communities (80\%). The first measure of success, self-fulfillment, is translated as a 
sense of achievement and accomplishment, an increase in self-esteem, and pride in one's work and performance. The study found that, through entrepreneurship, those women's confidence levels have increased, and they are proud of their achievements.

Financial achievement is also one of their success indicators. The majority (92\%) of them rated their entrepreneurial ventures as very profitable. Financial success of those agro-processors in Ghana is manifested in profitability and number of employees and business turnover, expanding of business through increasing space, and diversifying the business into other product lines. All of the respondents (100\%) expressed, with a sense of pride, that if they are not able to achieve anything else, they are able to provide adequately for their families through the benefits they derive from their enterprises. Another success indicator for them is wealth creation, manifested mainly in the acquisition of real estate and capital equipment. Nearly half (49\%) of the women entrepreneurs own the homes they live in and some $(20 \%)$ of them are in the process of building their own houses. In addition, more than half (61\%) of them had bought their own business premises, warehouses and factories.

Finally, the findings also indicated that the small agro-processing enterprises in Ghana have contributed economically $(75 \%)$ and socially $(90 \%)$ to the development and welfare of their country. The findings revealed that the creation of the small enterprises by the women impacts on the Ghanaian economic base as it creates new jobs and enlarges the tax pool. The large number of girls trained and equipped with knowledge and skills by the respondents has also created jobs and employment for others. Therefore, through the respondents' transfer of knowledge and skills to other citizens of Ghana, more employment avenues have been created.

The creation and development of these small enterprises have contributed positively to the social life of their communities and Ghana at large. These contributions are diverse and unquantifiable. The women entrepreneurs served as a source of inspiration and as role models for many young women. Some of the respondents in the service, manufacturing and agro-processing businesses said they sometimes train some of the girls from very poor homes without charging any fee. Above all, the women's entrepreneurial successes have played an important role in shaping the community's perception of women. The perception that women are financially dependent on men has declined very significantly.

\subsection{Hypotheses testing results}

Chi-square test was used in testing the hypotheses to ascertain the relationship between the independent variables (innovation: new products, new methods, new sources and new markets) and the dependent variable (success of women-owned enterprises in Ghana). Table 3 represents the Pearson Chi-square $\left(x^{2}\right)$ values for the relationship between success of women-owned small enterprises and their use of the innovative practices(including development of new products, use of new methods, sources of materials and markets). For the relationship between the success and new product development, Table 3 reports $x^{2}=2325.01 ; 693 \mathrm{df}, \mathrm{p}<0.000$; indicating a significant relationship between new products development and success of women- owned small enterprises in Ghana. This result therefore supported Hypothesis 1, and it indicated that innovation (development of new products) is related to the success of women-owned small enterprises in Ghana.

Table 3

Pearson $x^{2}$ value for relationship between success in small enterprise and use of innovative practices

\begin{tabular}{lrrrr}
\hline Innovative Practices & N & $\begin{array}{r}\text { Pearson } \\
\text { x }^{2} \text { value }\end{array}$ & df & $\begin{array}{c}\text { Asymp. Sig. } \\
\text { (2-sided) }\end{array}$ \\
\hline Success in small enterprises and development of new product & 421 & 2325.01 & 693 & .000 \\
Success in small enterprises and use of new methods & 421 & 801.14 & 297 & .000 \\
Success in small enterprises and use of new sources of materials & 421 & 1191.54 & 429 & .000 \\
Success in small enterprises and use of new markets & 421 & 947.99 & 396 & .000 \\
\hline
\end{tabular}


In testing of Hypothesis 2 , the results in Table 3 shows $\mathrm{X}^{2}=801.14 ; 297 \mathrm{df} ; \mathrm{p}<0.000$; that is the Chi-Square value 801.146 with 297 degree of freedom and a significance value which is less than 0.001 . This means that there is a significant relationship between new methods of production and success of the womenowned small enterprises in Ghana. Thus the results have confirmed Hypothesis 2. Also the results in Table 3 after testing Hypothesis 3 which shows the Chi - Square test results between the success of the women entrepreneurs and new sources of raw materials reports a value of 1191.541 with 429 degree of freedom and a significance value which is less than 0.001 . This means that there is a significant relationship between new market outlets and success of the women-owned small enterprises in Ghana. Hypothesis 4 has also been confirmed.

Therefore, all the four hypotheses predicting a significant relationship between innovation (new product development, new methods of production, new sources of raw materials and new markets) and successes of women-owned enterprises have been confirmed.

\section{Conclusion}

The study showed that over four hundred (400) different small enterprises (refer to Table 1) have been created and managed by women in the Eastern Region of Ghana. It was clear that in the creation and development of the entrepreneurial ventures, the majority of the women entrepreneurs have started up new enterprises, while some have taken over existing businesses from relatives, remodeled and expanded them.

The findings revealed that various types of innovative practices have been adopted in the small enterprises, which have contributed to success and growth. Some of the new practices include the diversification of product line; acquisition of raw materials from cheaper sources and in large quantities to reduce cost; and adoption of fuel efficient processing methods.

Significantly, technological innovations (comprising usage of new tools and equipment) facilitate production in large quantities and hence open the way for new marketing outlets and increased consumption. Production is now done in a more hygienic and friendly environment; work place accidents and cost of production have been significantly reduced. The study also primarily found that the small agro-processors interpret success broadly not only in terms of financial success but equally in terms of self-respect and fulfillment, family well-being, and contribution to the development of their nation. That departed from the traditional economic analysis of success based on financial and other physical measures of wealth.

Significantly, the findings supported Schumpeter's perspective of entrepreneurship. The women have identified profitable opportunities in their own unique environment with the available resources and socio-cultural demands, and created new businesses. Even those who took over existing businesses actually reshaped and remodeled them in substantial ways. Additionally, they are continually introducing innovation in the operations of their enterprises, and consequently achieving success. The innovations introduced by these small scale women entrepreneurs contribute largely to their success. This is evidence of innovative entrepreneurial activity. The outcome of the testing of the hypothesis confirmed that the innovations have statistically significant influences on their business success.

Clearly, the outcomes of the innovative activities of these women's small businesses have extended from economic profits to multiple social and economic advantages for their communities and Ghana as a whole. In view of these findings, if there is going to be any sustained development in Ghana, there is a need to recognize, understand and support these women's small enterprises so that their full potential can be developed to the benefit of Ghana, and other developing economies. It is, therefore, very important for all governments and policy institutes in developing economies, especially in Ghana to give all the necessary support and training to women operating small enterprises. They should be supportive with modern and improved technology, training in marketing strategies and financial management to increase their capabilities and competitiveness.

Business success also depends on opportunity structure and the government and institutional regulatory structures (Kloosterman and Rath, 2001) that ideally provide the optimal economic and business conditions for business start-ups and growth. There is a need for future research into the structures governments and other stakeholders in developing economies have put in place to create an enabling business environment for these women entrepreneurs, including the effectiveness of these measures for women entrepreneurs in SMEs. The findings in the study are limited by the extent to which the respondents are honest in responding to the survey instruments and the interviews. Also, the 
database obtained cannot be considered as an exhaustive list of all small businesses in Ghana. This notwithstanding, the paper provides an insight into the innovation and success relationship in SMEs' managed by women entrepreneurs in Ghana, and provides direction for further studies.

\section{References}

Bennet, R.J. and Dann, S., (2000). The Changing Experience of Australian Female Entrepreneurs.. Gender, Work Organization, Vol.7, no. 2, pp.75-83.

Bhide, A., (2000). The Origin and Evolution of Nerw Business, (1st Ed),.Oxford University Press, New York.

Bird, R.S. and Sapp, S.G., (2004). Understanding the Gender Gap in Small Business Success, Urban and Rural Comparisons, Gender E Society, Vol. 18, No.1.

Britwum, A. Ghartey, N. and Agbesinyale, P., (2006). Organizing Labour in the Informal Sector, The Conditions of Rural Agriculture in Ghana. Ghana Universities Press,Accra.

Brush, C.G. Carter, N., Gatewood, E., Greene, P. and Hart, M., (2006). Growth-Oriented Women Entrepreneurs and their Businesses: A Global Research Perspective, Edward Elgar Publishing, Cheltenham.

Butler, J., (2003).Nerw Perspectives on Women Entrepreneurs, Information Age Publishing Inc., Greenwich, Connecticut.

Buttner, E.H and Moore, D., (1997). Women's Organizational Exodus to Entrepreneurship: Self Reported Motivations and Correlates with Success, Journal of Small Business Management, Vol. 35, No.1, pp.34-47.

Choi, Y., (1995).The Entrepreneur: Schumpeter vrs Kirzner in IM Kirzner., (1999).Creativity and/or Alertness: A Reconsideration of the Schumpeterian.

Coughlin, J., (2002).The Rise of Women Entrepreneurs, Quorum, Westport, Connecticut.

Djik, B., (1996).Determinants of Successful Entrepreneurship, Doctoral Study, Erasmus University, Rotterdam, Monthly Labour Review, Vol. 17, No.3, pp. 20-69.

Dzisi, S., (2009). Women Entrepreneurs in Small and Medium Enterprises in Ghana: A Study of Women Entrepreneurs in Developing Economy, Lambert Academic Publishing AG \& Co. KG, Germany.
Dzisi, S. and Seddoh, J., (2009). Human and Financial Capital Factors in Entrepreneurial Success of Ghanaian Women: A Developing Country Perspective, Journal of Business and Enterprise Development, Vol.1, No.1 pp.102-119.

Fazlzadeh, A., and Moshiri, M.,(2010).An Investigation of Innovation in Small Scale Industries Located in Science Parks of Iran, International Journal of Business and Management Vol. 5, No. 10; October 2010. Framework, Academy of Management Review, No. 23,pp. 115-132.

Ghana Statistical Service, (2002). 2000 Population and Housing Census: Summary of Final Results, Ghana Statistical Services, Accra.

Glynn, M.A., (1996). Innovative Genius: A Framework for Relating Individual and Organizational Intelligences to Innovation, The Academy of Management Review, Vol.21 No. 4, pp. 1081-1111.

Hisrich, R. D., and Ozturk, S., (1999). Women Entrepreneurs in a Developing Economy, Journal of Management Development, Vol.18, No.2, pp.114-124.

Jalbert, S., (2000).Women Entrepreneurs in the Global Economy, Center for International Private Enterprise, Washington, DC.

Kanter, R.M., (1999). From Spare Change to Real Change: The Social Sector as Beta Site for Business Innovation, Harvard Business Review, Vol. 77 No.3, pp. 122-132.

Kirzner, I.M. ,(1999). Creativity and or Alertness: A Reconsideration of the Schumpeterian Entrepreneur, Review of Austrian Economics Vol.11, pp 5-17, Kluwer Academic Publishers.

Kloosterman, R., and Rath, J., (2000).Policies and Mixed Embeddedness. The Many Faces of Regulation, Paper presented at the Public Policy and the Institutional Context of Immigrant Businesses, Liverpool, England, March 22-25, 2001.

Lemon, M., and Sahota, P. S., (2004).Organisational Culture as a Knowledge Repository for Increased Innovative capacity. Technovation, Vol 24, pp. 483498.

Linder, J.C., Jarvenpaa, S. and Davenport, T.H., (2003). Towards an Innovation Sourcing Strategy, MIT Sloan Management Revierw, Vol. 44 No. 4, pp. 43(7) 
Mone, M.A., McKinley and W. Bargar, V.L., (1998). Organizational Decline and Innovation: a Contingency Framework, Academy of Management Review, No. 23, pp. 115-132.

Montalvo, (2006) What Triggers Change and Innovation? Technovation, Vol. 26, Issue 3, March 2006, pp 312-323

O'Regan, N., Ghobadian, A., and Gallear, D. ,(2006). In Search of the Drivers of High Growth in Manufacturing SMEs, Technovation, Vol.26, No. 1, pp $30-41$

Oke,A., Burke, G., and Myers, A., (2007). Innovation Types and Performance in Growing UK SMEs, International Journal of Operation and Production Management, Vol.27, No.7, pp.735-757.

Organization for Economic Co-operation and Development (OECD), (2004).Promoting Entrepreneurship and Innovative SMEs in a Global Economy: Towards a more Responsive and Inclusive Globalization Proceedings of OECD Conference on Women's Entrepreneurship: Issues and Policies', OECD, Istanbul, Turkey.

Porter, M. E., (1998). On Competition, Harvard Business School, Boston, Massachusetts.

Schumpeter, J.A., (1934). The Theory of Economic Development, Harvard University Press, Cambridge, Massachusetts.

Schumpeter, J.A., (1961). The Theory of Economic Development, Harvard University Press,Cambridge, Massachusetts.

Schumpeter, J.A., (1979). Capitalism, Socialism and Democracy, George Allen and Unwin,London, UK.
Simpson, M., Tuck, N., Bellamy, S.,(2004). Small Business Success Factors: The Role of Education and Training, Education E Training, Vol. 46 No. 8/9, pp.481 - 491.

Steel, W.F., and Webster, L., (1991). Small Enterprises under Adjustment in Ghana, World Bank Technical Paper No. 138, Industry and Finance Series, Washington DC: The World Bank.

Still, L., and Timms, W., (2000). Making a Difference: The Values, Motivations and Satisfaction, Measures of Success, operating Principles and Contributions of Women Small Business Owners, Centre for Women and Business', Discussion Paper Series, University of Western Australia, No. 1, pp.3-18.

United Nations Conference on Trade and Development (UNCTD), (2005). Improving the Competitiveness of SMEs through Enhancing Productive Capacity, Proceedings of Four Expert Meetings United Nations, New York and Geneva.

Wennekers, S., and Thurik, R., (1999). Linking Entrepreneurship and Economic Growth, Small Business Economics, vol. 13, pp. 27-55.

Zahra, S.A., Nielsen, A.P. and Bognar, W.C., (1999). Corporate Entrepreneurship, Knowledge and Competence Development, Entrepreneurship: Theory and Practice, Vol. 23, No.3, pp. 169-189.

Zott, C., (2003). Dynamic Capabilities and the Emergence of Intra Industry Differential Firm Performance: Insights from a Simulation Study, Strategic Management Journal, Vol. 24, No 2, pp. 97-126. 